\title{
POLSKA HISTORIOGRAFIA PROCESÓW O CZARY. ZARYS PROBLEMU
}

\section{Łukasz HAJDRYCH}

\section{ABSTRACT}

\section{POLISH HISTORIOGRAPHY OF WITCH-TRIALS. ISSUE OVERVIEW}

Over the last 20 years in Poland there has been a great increase in interest in witch trials of modern times. This paper gathers information about the most important Polish papers written on that subject and published between 1925 and 2016. The paper especially focuses on the period after World War II, when the subject of witch trials was researched by B. Baranowski, as well as on modern times (represented by M. Pilaszek, J. Wijaczka and T. Wiślicz).

\section{KEYWORDS:}

historiography, Poland, witchcraft, witches, witchcraft trials 
W ciągu ostatnich kilkunastu lat w polskiej historiografii na dobre zagościła tematyka nowożytnych procesów o czary. Od początku lat dwutysięcznych systematycznie rośnie w naszym kraju liczba wydawanych artykułów oraz książek poświęconych różnym aspektom tego zagadnienia. Pomimo tego, że raz po raz pojawiają się, na polskim gruncie, apele o większe zainteresowanie badaczy zjawiskiem czarownictwa w okresie nowożytnym, a także o prowadzenie w tym zakresie szerzej zakrojonych badań podstawowych, już dziś trudno zapoznać się z całą literaturą przedmiotu dostępną w naszym języku. Celem mojego artykułu jest zebranie w jednym miejscu informacji na temat najważniejszych polskich opracowań naukowych poświęconych problemowi polowania na czarownice, poruszanej przez nie tematyki oraz naszkicowanie zmian w podejściu do tematu, które zaobserwować można na przestrzeni lat.

Pomimo tego, że pierwsze prace naukowe dotyczące sądzenia „wspólniczek Szatana” stworzyli Polacy jeszcze w XIX wieku', swój artykuł chciałbym poświęcić badaniom prowadzonym od końca I wojny światowej. Cezurę początkową stanowi dla mnie apel Kazimierza Sochaniewicza z 1925 roku, opublikowany w czasopiśmie „Lud”, zaś końcową zakończony niedawno 2016 r.

Sochaniewicz wygłosił po raz pierwszy wspomniany apel w trakcie XII zjazdu lekarzy i przyrodników w Warszawie. Zwracał w nim uwagę m.in. na konieczność regularnego wydawania materiałów źródłowych poświęconych procesom o czary. Jak napisał we wstępie do przedruku swojego wystąpienia:

materjały, odnoszące się do wierzeń i przesądów wogóle, a do historji czarów w szczególności, nie są należycie, jednolicie i systematycznie opublikowane. [...] Wskutek tego stan jest tego rodzaju, że badający historię czarów i czarownic musi tego materjału poszukiwać nie tylko w pracach Kolberga, w rocznikach „Wisły” $i$ „Ludu”, ale ponadto w całym szeregu publikacyj, których tytuł zupełnie nie zdradza jakiegokolwiek związku z badanym materjałem².

Sochaniewicz podkreślał również doskwierający brak polskich rozpraw, które podjęłyby próbę całościowego ujęcia tematu³.

Por. m.in.: R. W. Berwiński, Studia o gustach, czarach i zabobonach, t. I-II, Poznań 1862; Muzeum Literatury im. Adama Mickiewicza w Warszawie, J. Mickiewicz, rkps 127 i in.

2 K. Sochaniewicz, O potrzebie systematycznego wydawnictwa materjatów do historii procesów o czary w Polsce: referat wygtoszony na XII Zjeździe Lekarzy i Przyrodników w Warszawie, „Lud”, t.24, 1925, s. 165-166.

3 Tamże, s. 165. 
Jednym z pierwszych, którzy zareagowali na propozycję historyka, był Adam Fischer ${ }^{4}$. Jako etnograf i folklorysta nie podjął się jednak badania źródeł wczesnonowożytnych, a zamiast tego skupił się na rękopiśmiennych relacjach z połowy XIX wieku, które odkrył w Bibliotece Ossolińskich - zbiorze opowieści na temat czarownic-boginek zebranych wśród mieszkańców doliny nowotarskiej na Podhalu.

Na szeroką skalę temat późnośredniowiecznych i nowożytnych procesów o czary podjął za to uczeń A. Fischera, Karol Koranyi ${ }^{5}$. Na przestrzeni lat opublikował on szereg artykułów poświęconych temu zjawisku, m.in. wziął na warsztat analizę problematyki czarostwa z punktu widzenia historyka prawa („Czary w postępowaniu sądowym [szkic prawno-etnologiczny]”, Lwów 1927; „Ze studiów nad wierzeniami w historii prawa karnego. I. Beczka czarownic", Lwów 1928). Pomimo tego, że tak, jak i jego mistrz, nie stronił od zagadnień etnologicznych („Łysa Góra. Studium z dziejów wierzeń ludowych w Polsce w XVII i XVIII wieku”, Lwów 1928), to przez wiele lat swoje szkice poświęcone zagadnieniu czarownic ograniczał do wieków XV-XVIII, późniejsze relikty tych wierzeń pozostawiając folklorystom.

Badania prowadzone przez K. Koranyiego przerwane zostały przez wybuch II wojny światowej. Po 1945 roku nie powrócił on już w zasadzie do tematu ${ }^{6}$, a tematyka

4 Adam Fischer (1889-1943) - etnograf i folklorysta, profesor etnografii na Uniwersytecie Lwowskim. W latach 1914-1939 redaktor czasopisma „Lud”. Autor prac: Czarownice w dolinie nowotarskiej, Lwów 1927; Tenże, Etnografia stowiańska, z. 1-3 (Połabianie, Łużyczanie, Polacy), Lwów 1932-1934. Więcej informacji (wraz z bibliografią): J. Krzyżanowski, Stownik folkloru polskiego, red. J. Krzyżanowski Warszawa 1965, s. 103 (hasło: Fischer Adam); J. Gajek, Adam Fischer, „Lud” 36/1946, s. 6-18.

5 Karol Koranyi (1897-1964) - polski etnolog i historyk prawa. Absolwent Uniwersytetu Lwowskiego, uczeń A. Fischera. W latach 1945-1948 prorektor na Uniwersytecie im. Mikołaja Kopernika w Toruniu. Od 1957 roku pracował w Instytucie Nauk Prawnych PAN, a po zmianach w organizacji struktury Akademii: w Instytucie Historii PAN. Obok prac poświęconych stricte zagadnieniom prawnym, napisał również kilka wartościowych prac dot. procesów o czary: K. Koranyi, Czy tortury są dalszym ciagiem sądów bożych?, „Lud” 25/1926, s. 96-97; Tenże, Czary w postępowaniu sądowym (szkic prawno-etnologiczny), Lwów 1927; Tenże, Czary i gusła przed sądami kościelnymi $w$ Polsce $w$ XV i w pierwszej połowie XVI wieku, Lwów 1928; Tenże, Ze studiów nad wierzeniami w historii prawa karnego. I. Beczka czarownic, Lwów 1928; Tenże, Łysa Góra. Studium z dziejów wierzeń ludowych w Polsce w XVII $i$ XVIII wieku, Lwów 1929. Więcej informacji: Pracownicy nauki i dydaktyki Uniwersytetu Mikotaja Kopernika 1945- 2004, red. S. Kalemba, Toruń 2006, s. 355-356; http://torun.ptl.info.pl/dawni-czlonkowie/prof-karol-koranyi [dostęp: 5-05-2017].

6 Na początku lat 50. K. Koranyi wystąpił na posiedzeniu Poznańskiego Towarzystwa Przyjaciół Nauk z referatem poświęconym Księdze wójtowskiej miasta Kleczewa, pochodzącemu z XVII i XVIII wieku zbiorowi zapisów kilkudziesięciu procesów o czary z rejonu wschodniej Wielkopolski. Przed 1939 r. był to jeden z najcenniejszych zabytków piśmienniczych PTPN-u, w czasie wojny zaginiony. Koranyi, który dysponował własnoręcznym odpisem całości źródła, wykonanym jeszcze w trakcie badań prowadzonych w latach 20., zaproponował na posiedzeniu wykonanie maszynowej kopii. Swoją pracę szybko jednak porzucił, uświadomiwszy sobie, że zanadto odbiegała ona od przyjętych standardów edycji źródłowych. Oryginał Księgi..., w oparciu o który K. Koranyi mógłby dokończyć swoją pracę, odnalazł się dopiero po śmierci historyka. Więcej na ten temat: T. Wiślicz, Społeczeństwo Kleczewa i okolic w walce z czartem (1624-1700), „Kwartalnik Historyczny”, z. 2, 2004, s. 38; K. Koranyi, Księga miasta Kleczewa (1624-1730), „Sprawozdania PTPN” 1950/51, nr 1 (42), s. 84 (streszczenie wystąpienia). 
czarownictwa i magii pozostały w Polsce głównie domeną etnologów. Jedynym tak naprawdę historykiem, który podjął się analizy zjawiska na szerszą skalę był Bohdan Baranowski ${ }^{7}$, twórca tzw. łódzkiej szkoły etnografii historycznej.

Pierwsze prace poświęcone temu zagadnieniu łódzki historyk opublikował jeszcze pod koniec lat 40. i na początku 50. (były to jego najważniejsze prace naukowe związane $\mathrm{z}$ tematem i to do nich w większości odnoszą się dzisiejsi historycy; późniejsze opracowania miały charakter głównie popularno-naukowy i powielały wcześniejsze tezy, nie podejmując przy tym głębszej refleksji źródłowej). W pracach tych B. Baranowski podjął się zarysowania problematyki i skali zjawiska, wydał drukiem zbiory materiałów poświęcone procesom o czary w Kaliszu, a także, razem z Władysławem Lewandowskim, wierzeniom demonicznym w okresie staropolskim.

Niestety, chociaż należy przyznać rację uczniom B. Baranowskiego, którzy chwalili go m.in. za znaczący wkład w rozwój polskiej metodologii badań historycznych i „przezwyciężenie stereotypu metodologicznego klasycznej etnografii” ${ }^{8}$ oraz oddać autorowi hołd za zasługi na polu spopularyzowania tematyki procesów o czary w polskim dyskursie historycznym, to dodać należy, że nie ustrzegł się on także rażących błędów metodologicznych, które dziś w zasadzie usuwają go poza obręb uznanych autorytetów w tej dziedzinie.

7 Bohdan Baranowski (1915-1993) - profesor, doktor honoris causa Uniwersytetu Łódzkiego, gdzie pracował po II wojnie światowej. Zasłynął z położenia podwalin pod szkołę tzw. etnografii historycznej. Autor wielu opracowań dot. zagadnień gospodarczo społecznych Polski w XVI-XVIII wieku, historii kultury oraz historii wojskowości. Autor takich prac poświęconych procesom o czary i demonologii jak: B. Baranowski, Procesy czarownic w dawnej Polsce, „Problemy” 7/1949, s. 461-467; Tenże, Najdawniejsze procesy o czary w Kaliszu, Lublin-Łódź 1951; Tenże, Procesy czarownic w Polsce w XVII i XVIII wieku, Łódź 1952; Tenże, Wielki proces o czary miłosne w Praszce w 1665 r., „Eódzkie Studia Etnograficzne", t. IV, 1962, s. 14-15; Tenże, Pożegnanie z diabtem i czarownica, Łódź 1965; Tenże, Z badań nad dawną demonologia ludowa (relikty wierzeń w upiory-strzygonie na terytorium woj. łódzkiego), Łódź 1965; Tenże, Kultura ludowa XVII i XVIII w. na ziemiach Polski Środkowej, Łódź 1971; Tenże, W kręgu upiorów i wilkołaków, Łódź 1981; Tenże, W. Lewandowski, Nietolerancja i zabobon w Polsce w XVII i XVIII w., Warszawa 1987; Tenże, O hultajach, wiedźmach i wszetecznicach: szkice z obyczajów XVII i XVIII wieku, Łódź 1988.

8 A. Lech, Etnografia historyczna w ujęciu Bohdana Baranowskiego (w 100. rocznicę urodzin Mistrza), „Zeszyty wiejskie”, z. XXI, Łódź 2015, s. 8. 
Współcześnie, obszerną krytykę prac B. Baranowskiego przeprowadzili w swoich artykułach m.in. Małgorzata Pilaszek ${ }^{9}$ i Jacek Wijaczka ${ }^{10}$. Oboje zarzucili autorowi przede wszystkim ograniczenie przeprowadzonych badań do terytorium powojennej Polski. Olbrzymie obszary wschodnich terenów I Rzeczpospolitej, które po II wojnie światowej weszły w skład ZSRR, zostały całkowicie przez niego pominięte, stąd też podawane w jego pacach dane szacunkowe, dotyczące natężenia i skali zjawiska polskich procesów o czary, są przekłamane $e^{11}$. Poważne zastrzeżenia w jego pracach budzi także dobór źródeł, ponieważ B. Baranowski nie stronił od wysuwania wniosków ogólnych, dotyczących całego kraju, na podstawie wąskiego wycinka materiałów archiwalnych z terenu Wielkopolski (a i w tym przypadku ograniczył się przede wszystkim do czterech województw: łęczyckiego, sieradzkiego, kaliskiego i ziemi wieluńskiej, w dużo mniejszym stopniu odnosząc się do województwa poznańskiego) ${ }^{12}$.

Zdaniem M. Pilaszek wątpliwości budzi dziś również sposób wykorzystania źródeł przez B. Baranowskiego: niestaranność w sporządzaniu przypisów (a właściwie częsty ich brak, utrudniający, a czasami wręcz uniemożliwiający odbiorcy weryfikację wysuwanych przez autora tez), silne akcentowanie walki klas, która leżeć miałaby

9 Małgorzata Pilaszek - od 2006 doktor, absolwentka Uniwersytetu Warszawskiego, uczennica prof. Antoniego Mączaka oraz prof. Wojciecha Tygielskiego. Specjalizuje się w zagadnieniu polskich procesów o czary. Najważniejsze prace: M. Pilaszek, Procesy o czary w Polsce w XVI-XVIII wieku. Nowe aspekty. Uwagi na marginesie pracy B. Baranowskiego, „Odrodzenie i Reformacja w Polsce”, XLII/ 1998, s. 81-103; Tejże, Fiasko europejskiego polowania na czarownice? : (na marginesie pracy Robina Briggsa, Witches \& Neighbors. The Social and Cultural Context of European Witchcraft, London 1996), „Przegląd Historyczny”, z. 4, 2001, s. 461-475; Tejże, Litewskie procesy czarownic w XVI-XVIII w., „Odrodzenie i Reformacja w Polsce”, XLVI/ 2002, s. 7-35; Tejże, Witch-hunts in Poland, 16th-18th centuries, "Acta Poloniae Historica”, 86/ 2002, s. 103-132; Tejże, Procesy o czary w Polsce w wiekach XV-XVIII, Kraków 2007.

10 Jacek Wijaczka (ur. 1960) - profesor, w latach 2011-2014 Dyrektor Instytutu Historii i Archiwistyki UMK, od 2008 roku redaktor naczelny czasopisma „Czasy Nowożytne”, członek Rady Naukowej Instytutu Historii PAN na lata 2015-2018. Specjalizuje się w stosunkach polsko-niemieckich w czasach nowożytnych, dziejach Prus Królewskich i Książęcych, procesach o czary oraz historii Żydów w okresie staropolskim. Spośród jego prac poświęconych procesom o czary należy wymienić: J. Wijaczka, Procesy o czary w regionie świętokrzyskim $w$ XVII-XVIII wieku, [w: ] Z przeszłości regionu świętokrzyskiego od XVI do XX wieku, red. J. Wijaczka, Kielce 2003, s. 37-72; Tenże, Proces o czary we wsi Młotkowo w 1692 roku. Przyczynek do polowania na czarownice w Rzeczypospolitej w XVII wieku, „Odrodzenie i Reformacja w Polsce” XLVIII/2004, s. 161-170; Tenże, Mężczyźni jako ofiary procesów o czary przed sądem tobżenickim $w$ drugiej potowie XVII wieku, „Czasy Nowożytne”, 17/2004, s. 17-30; Tenże, Procesy o czary w Polsce $w$ dobie Oświecenia. Zarys problematyki, „Klio. Czasopismo poświęcone dziejom Polski i powszechnym” 7/2005, s. 17-62; Tenże, Procesy o czary w Prusach Królewskich (Brandenburskich) w XVI-XVIII wieku, Toruń 2007; Tenże, Postępowanie sądowe w sprawie o czary w Toruniu w 1712 roku, „Odrodzenie i Reformacja” 52/2007, s. 199-212; Tenże, Procesy o czary przed sądem miejskim w Grudziądzu w XVI-XVII wieku, „Rocznik Grudziądzki” 2009, s. 89-101; Tenże, Procesy o czary we wsi Osowo z 1686 roku, „Czasy Nowożytne”, 24/ 2011, s. 221-230; Tenże, Oskarżenia i procesy o czary w Koźminie w XVII-XVIII wieku, „Roczniki Historyczne” 2016, s. 197-219; Tenże, Próba zimnej wody (pławienie) w oskarżeniach i procesach o czary w państwie polsko-litewskim w XVI-XVIII wieku, „Odrodzenie i Reformacja w Polsce” LX/ 2016, s. 73-110; Tenże, Kościół wobec procesów o czary w Rzeczypospolitej w XVI-XVIII wieku, Warszawa 2016.

11 M. Pilaszek, Procesy o czary w Polsce w XVI- XVIII wieku. Nowe aspekty. Uwagi na marginesie pracy B. Baranowskiego, „Odrodzenie i Reformacja w Polsce”, XLII/ 1998, s. 81; J. Wijaczka, Procesy o czary we wsi Osowo z 1686 roku, „Czasy Nowożytne”, 24/ 2011, s. 221.

12 M. Pilaszek, Procesy o czary... Uwagi na marginesie pracy..., s. 82. 
u podstaw polskich procesów o czary (co akurat wydaje się zrozumiałe, biorąc pod uwagę, że najobszerniejsze opracowania problemu wydał Baranowski jeszcze w okresie stalinowskim), a także nadmierne eksponowanie roli Kościoła w rozpętaniu „nagonki” na wspólniczki szatana ${ }^{13}$.

W czasie, gdy łódzki historyk tworzył kolejne popularno-naukowe opracowania problemu, temat europejskich procesów o czary na dobre zagościł w nauce zachodniej. Szczególnie w latach 60. i 70. XX wieku w literaturze angielskiej zaczęły pojawiać się coraz to nowsze propozycje ujęcia zjawiska, z użyciem wcześniej niewykorzystywanych metod badawczych, m.in. antropologii kulturowej.

Tematyka procesów o czary wpisała się na Zachodzie w ogólną modę przełomu lat 60. i 70. na podejmowanie zagadnień dotyczących ludzi marginesu, dołów społecznych, mentalności chłopów i mieszczan, etc. To właśnie w tym czasie we Francji Emmanuel Le Roy Ladurie tworzy swoje klasyczne prace dotyczące mentalności chłopów oraz historii klimatu ${ }^{14}$, Michel Foucault publikuje prace poświęcone m.in. historii szaleństwa, seksualności oraz relacji władzy ${ }^{15}$, Philippe Ariès podejmuje tematykę historii dzieciństwa w czasach Ancient Regime' $u^{16}$ i zagadnienia śmierci w kulturze Zachodu ${ }^{17}$, a Robert Mandrou wydaje kolejne książki poświęcone kulturze popularnej ${ }^{18}$ oraz nizinom społecznym w dawnej Francji ${ }^{19}$. We Włoszech na początku lat 70. Carlo Ginzburg wydaje swoje pierwsze prace poświęcone zagadnieniom religii ${ }^{20}$, a w USA Natalie Zemon Davies podejmuje studia nad społeczeństwem wczesnonowożytnej Francji ${ }^{21}$.

Jednocześnie wielu z nich podejmuje w tym czasie także kwestie historii czarownictwa, herezji lub ewolucji myślenia na temat magii na zachodzie Europy w późnym średniowieczu i wczesnej nowożytności. Prace, często utrzymane w duchu mikrohistorii, poświęcone są niemal wszystkim regionom Europy. Carlo Ginzburg w swoich książkach opisuje specyficzną dla południa kontynentu wiarę w walczących we śnie z czarownicami benandanti, którzy pomiędzy połową XV i XVI wieku sami zostali

13 Tamże.

14 E. Le Roy Ladurie, Les paysans de Languedoc, Paris 1996; Tenże, Histoire de climat depuis l'an mil, Paris 1967; Tenże, Montaillou, vilage occitan de 1294 à 1324, Paris 1975.

15 M. Foucault, Historie de la folie à l'âge Classique, Paris 1961; Tenże, Surveiller et punir, Paris 1975; Tenże, Historie de la sexualitè, t. I, Paris 1976.

16 P. Ariès, L'Enfant et la vie familiale sous l'Ancient Règime, Paris 1960.

17 Tenże, Essais sur l'histoire de la mort en Occident: du Moyen Âge à nos jours, Seuil 1975; Tenże, L'Homme devant de la mort, Seuil 1977.

18 R. Mandrou, De la culture populaire en France aux XVIIe et XVIIIe siècles, Paris 1964.

19 Tenże, Classes et luttes de classes dans la France du XVIIe siècle, Paris 1965; Tenże, La France des XVIe et XVII ${ }^{e}$ siècles, Paris 1967.

20 C. Ginzburg, Il nicodemismo. Simulazione e dissimulazione religiosa nell'Europa del Cinquecento, Torino 1970; Tenże, Folklore, magia, religione, [w: ] Storia d'Italia, vol. 1, Torino 1970, s. 604-676.

21 N. Z, Davies, Society and Culture in Early Modern France: Eight Essays, Stanford 1975. 
uznani za heretyków i ścigani na równi ze swoimi dawnymi wrogami ${ }^{22}$. W 1968 roku R. Mandrou powraca do swojego dawnego tematu pracy doktorskiej książką poświęconą walce francuskich magistratów miejskich z problemem czarownic ${ }^{23}$. Wiele nowatorskich prac poświęconych zagadnieniu powstaje w tym czasie w języku angielskim ${ }^{24}$. Wśród nich pojawiają się także pewne uogólnienia dotychące historii czarownictwa na gruncie ogólnoeuropejskim (m.in. artykuł Mircea Elliadego w XIV tomie „History of Religions" ${ }^{25}$ ).

Większość z wymienionych powyżej prac nie była w latach 60. i 70. XX wieku powszechnie znana rodzimym historykom. W tym czasie w Polsce prym nadal wiodty prace B. Baranowskiego, nie przynoszące już jednak nowych informacji w stosunku do wcześniej poczynionych ustaleń.

Badania prowadzone przez łódzkiego historyka zachęciły co prawda kilku innych badaczy historii do zmierzenia się z tematem, trzymali się oni jednak ściśle ścieżki i tez wyznaczonych przez B. Baranowskiego. Wśród nich wymienić należy m.in. Barbarę Janiszewską-Mincer ${ }^{26}$, Genowefę Adamczewskąa ${ }^{27}$ i Zenona Guldona ${ }^{28}$ (wybór ten przytaczam za M. Pilaszek ${ }^{29}$ ). Prace ich autorstwa były przede wszystkim pracami o charakterze regionalnym, stanowiącymi dziś głównie wkład w badania podstawowe nad procesami o czary (wciąż nader skąpe) i udostępniającymi nam informacje o istnieniu konkretnych zapisków archiwalnych.

Nowe podejście do tematu zaprezentował dopiero pod koniec lat 70. Janusz Tazbir. W opublikowanym w „Odrodzeniu i Reformacji w Polsce” artykule „Procesy o czary”30 zaprezentował nowe, syntetyczne ujęcie tematu, które uwzględniało m.in. specyfikę religijną XVI-wiecznej Polski oraz uwarunkowania geograficzne polowań na czarownice.

22 C. Ginzburg, I benandanti. Ricerche sulla stragoneria e sui culti agrari tra Cinquecento e Seicento, Torino 1966.

23 R. Mandrou, Magistrats et sorciers en France au XVIIe siècle, Paris 1968.

24 H. Trevor-Roper, The European Witch-Craze of the Sixteenth and Seventeenth Centuries, New York 1968; K. Thomas, Religion and the Decline of Magic: studies in popular beliefs in sixteenth and seventeenth century England, London 1971; H. C. E. Middlefort, Witch Hunting in Southwestern Germany 1562-1684: The Social and Intellectual Fundation, Stanford 1975; N. Cohn, Europe's Inner Demons: An Enquiry Inspired by the Great Witch-Hunt, Sussex-London 1975;

25 M. Eliade, Some Observations on European Witchcraft, [w:] History of Religions, vol. XIV, no. 3 (1975), s. $149-172$.

26 B. Janiszewska-Mincer, Bydgoski proces o czary w 1638 roku, [w:] Prace Komisji Historii, t. III, seria C, Bydgoszcz 1966, s. 105-124; Tejże, Diabet „Węgliszek” i czarownice, [w: ] „Kalendarz Bydgoski” 1970, s. 61-66; Tejże, Kulisy procesu o czary, [w: ],Kalendarz Bydgoski” 2008, s. 206-211.

27 G. Adamczewska, Magiczna broń i jej rola $w$ walce między wsią a dworem $w$ Sieradzkiem $w$ XVII-XVIII $w$., „É́dzkie Studia Etnograficzne” 1963, s. 5-16.

28 Z. Guldon, Proces czarownicy we wsi Staniszewo w 1695 r., „Studia z Dziejów Kościoła Katolickiego”, t. I, 1961, s. 150-161.

29 M. Pilaszek, Procesy o czary..., s. 41-42.

30 J. Tazbir, Procesy o czary, „Odrodzenie i Reformacja w Polsce”, t. XXIII, 1978, s. 151-177. 
To, co wyróżniało artykuł J. Tazbira na tle innych prac tego okresu poświęconych zagadnieniu czarostwa, to zakotwiczenie w aktualnej wówczas zagranicznej literaturze przedmiotu. Znał on i potrafił odnieść więc do lokalnej specyfiki prace takich autorów, jak Hugh Trevor-Roper ${ }^{31}$, Carlo Ginzburg ${ }^{32}$, Keith Thomas ${ }^{33}$ i Robert Mandrou ${ }^{34}$. Znacznie obszerniej niż poprzednik przedstawił również początki polowań na czarownice (uwzględniając takie czynniki, jak pogorszenie się sytuacji bytowej ludności w XVII wieku i wzrost frustracji społecznych, które można było rozładować poprzez egzekucję domniemanej winowajczyni), a w swoich rozważaniach poruszył m.in. seksualny aspekt czarownictwa i mitu sabatu.

Niestety, odkrywczy, jak na ówczesne czasy, artykuł J. Tazbira nie rozbudził wśród polskich historyków zainteresowania nowożytnymi procesami o czary, a lata 80. nie przyniosły żadnego znaczącego odkrycia w omawianej dziedzinie. Badacze okresu staropolskiego większą uwagą obdarzyli owe procesy dopiero w następnej dekadzie.

Od połowy lat 90. XX wieku zaobserwować można wzrost zainteresowania procesami o czary u trójki historyków, których prace w kolejnych latach będą stanowić główne źródło opracowań tematu na gruncie polskim. Są to odpowiednio Tomasz Wiślicz $^{35}$, Jacek Wijaczka oraz najmłodsza z nich, w tym czasie przygotowująca dopiero rozprawę doktorską, Małgorzata Pilaszek. Pierwszy z nich podejmuje tematykę polowania na czarownice głównie w kontekście zagadnień religijności na wsi polskiej w okresie nowożytnym („Czary przed sądami wiejskimi w Polsce”, 1997). Jacek

31 H. R. Trevor-Roper, La caccia alle streghe in Europa nel Cinquecento e nel Seicento, [w: ] Tegoż, Protestantismo e transformazione sociale, Bari 1969.

32 C. Ginzburg, I benandanti..., Torino 1966.

$33 \mathrm{~K}$. Thomas, Znaczenie antropologii społecznej dla badań historycznych nad czarami w Anglii, „Odrodzenie i Reformacja w Polsce", t. XXII, 1977, s. 27-56.

34 R. Mandrou, Magistrats et sorciers..., Paris 1968.

35 Tomasz Wiślicz (ur. 1969) - w latach 1994-2013 asystent, następnie adiunkt w Zakładzie Dziejów Nowożytnych Polskiej Akademii Nauk w Warszawie, od 2013 profesor w tymże zakładzie. Specjalista w zakresie zagadnień obyczajowych i religijnych w okresie nowożytnym. Autor kilku (również popularno-naukowych) prac dotyczących procesów o czary i demonologii w okresie nowożytnym: T. Wiślicz, Czary przed sądami wiejskimi w Polsce, „Czasopismo Prawno-Historyczne”, XLIX/ 1997, z. 1-2, s. 47-63; Tenże, Languages of Witchcraft. Narrative, Ideology and Meaning in Early Modern Culture, ed. S. Clark, Basingstoke 2001, [recenzja], „Przeglad Historyczny”, XCIII/ 2002, z. 2 s. 247-253; Tenże, Igraszki z diabtem. Procesy o czary w Rzeczypospolitej, [w:] Sekrety historii Polski. Tego nie uczyli nas $w$ szkole, red. Z. Klimaszewska, Warszawa 2003, s. 174-177; Tenże, The Township of Kleczew and its Neighbourhood Fighting the Devil (1624-1700), „Acta Poloniae Historica”, 89/ 2004, s. 65-95; Tenże, Tto spoteczne procesów o czary w Kleczewie i okolicy. Próba ujęcia liczbowego, [w:] Cywilizacja prowincji Rzeczypospolitej szlacheckiej, red. A. Jankowski, A. Klonder, Bydgoszcz 2004, s. 229-244; Tenże, Społeczeństwo Kleczewa i okolic w walce z czartem 1624-1700”, „Kwartalnik Historyczny”, z. 2, 2004, s. 37-60; Tenże, Religijność wiejska w Rzeczypospolitej szlacheckiej. Problemy i trzy przyblizenia, „Barok”, t. XI, 2004, s. 97-112; Talking to the Devil in the Early Modern Popular Imagination, [w: ] Faith and Fantasy in the Renaissance. Texts, Images, and Religious Practices, ed. O. Zorzi Pugliese, E. M. Kavaler, Toronto 2009, s. 135-146; Tenże, Bezczeszczenie zwłok a podejrzenie o wampiryzm w Karpatach (XVII- XIX w.), „Kwartalnik Historii Kultury Materialnej”, 2012, s. 199-204; P. Rutkowski, Kot czarownicy. Demon osobisty w Anglii wczesnonowożytnej, Kraków 2012, [recenzja], „Kwartalnik Historyczny”, z. 3, 2014, s. 633-641. 
Wijaczka kieruje uwagę w swoich pracach bardziej ku zagadnieniom prawnym, które siedemdziesiąt lat wcześniej podejmował K. Koranyi. Z kolei M. Pilaszek w 1998 roku publikuje artykuł, który uznać chyba można za ostateczne zerwanie z powojennymi tezami B. Baranowskiego na temat procesów o czary („Procesy o czary w Polsce w XVI- XVIII wieku. Nowe aspekty. Uwagi na marginesie pracy B. Baranowskiego”).

Początek nowego tysiąclecia to kolejne artykuły J. Wijaczki, który w kolejnych pracach podejmuje temat m.in. problemu mężczyzn oskarżanych o czary („Mężczyźni jako ofiary procesów o czary przed sądem łobżenickim w drugiej połowie XVII wieku”, 2004), a Małgorzata Pilaszek publikuje wówczas trzy mniej lub bardziej ściśle związane z Polską teksty („Fiasko europejskiego polowania na czarownice? (na marginesie pracy Robina Briggsa, Witches \& Neighbors. The Social and Cultural Context of European Witchcraft”, 2001; „Litewskie procesy czarownic w XVI- XVIII w., 2002; „Witch-hunts in Poland, 16th-18th centuries”, 2002).

W 2004 roku T. Wiślicz podejmuje temat procesów o czary, wykorzystując m.in. źródła poświęcone kleczewskim procesom o czary („The Township of Kleczew and its Neighbourhood Fighting the Devil (1624-1700)”; „Religijność wiejska w Rzeczypospolitej szlacheckiej. Problemy i trzy przybliżenia”; „Tło społeczne procesów o czary w Kleczewie i okolicy. Próba ujęcia liczbowego”). W tym czasie J. Wijaczka zaczyna publikować głównie artykuły ograniczające analizę zagadnienia do pojedynczych miejscowości („Postępowanie sądowe w sprawie o czary w Toruniu w 1712 roku”, 2007; „Procesy o czary przed sądem miejskim w Grudziądzu w XVI-XVII wieku”, 2009; „Procesy o czary we wsi Osowo z 1686 roku”, 2011; „Oskarżenia i procesy o czary w Koźminie w XVII-XVIII wieku”, 2016).

Ostatnie dziesięć lat, to czas gdy na gruncie polskim powstało szczególnie dużo monografii poświęconych polowaniu na czarownice. W 2007 roku, nakładem krakowskiego wydawnictwa Universitas, ukazała się, najobszerniejsza do tej pory, synteza procesów o czary: „Procesy o czary w Polsce w wiekach XV-XVIII”, autorstwa M. Pilaszek (jest to przeredagowana wersja jej rozprawy doktorskiej). Na ponad pięciuset stronach autorka prześledziła m.in. problemy związane z klasyfikacją pojęcia czarów w językach europejskich („Jak opisać czary?”, s. 17-46), przedstawiła czynniki, które ułatwiły wystąpienie problemu na kontynencie europejskim („Szaleństwo czarownic - zjawisko i jego podstawy”, s. 47-126), przeanalizowała stosunek kościoła do domniemanych czarownic („Vox Dei”, s. 127-179), przejęcie kompetencji w sądzeniu tego typu spraw przez sądy świeckie („Świeckie ramię sprawiedliwości”, s. 180-226), możliwość odwołania się w procesie do sądu wyższej instancji, m.in. Sądu Wyższego Prawa Niemieckiego na Zamku w Krakowie („Apelacje”, s. 227-265), dynamikę 
opisywanego zjawiska (s. 266-338), a także nakreśliła wyobrażenie świata nadprzyrodzonego w kulturze staropolskiej („Zaklęte rewiry - miasta i wsie”, s. 339-389; „Świat czarownic”, s. 390-461). Całość zaopatrzona została w aneksy zestawiające procesy o czary w różnych prowincjach państwa polskiego oraz przedstawiające natężenie zjawiska na przestrzeni wieków.

Książka M. Pilaszek, chociaż ważna, stanowiąca bowiem pierwsze całościowe, poważne ujęcie tematu od czasów „Procesów o czary w Polsce w XVII i XVIII wieku” B. Baranowskiego, nie ustrzegła się jednak krytyki. W recenzji opublikowanej na łamach „Kwartalnika Historycznego” J. Wijaczka zarzucił jej przede wszystkim uproszczoną wizję genezy średniowiecznych procesów o czary ${ }^{36}$, podawanie wzajemnie sprzecznych ze sobą danych dotyczących ilości procesów ${ }^{37}$, przecenianie poziomu alfabetyzacji społeczeństwa polskiego ${ }^{38}$, czy niezrozumienie kwestii kulturowych, które wpłynęły na fakt, że zdecydowaną większość osób oskarżonych o czary w Europie stanowiły kobiety $^{39}$. Pomimo tego, publikacja M. Pilaszek nadal pozostaje najbardziej aktualną i kompletną syntezą zjawiska na gruncie polskim.

W tym samym roku ukazało się także opracowanie pruskich procesów o czary, przygotowane przez J. Wijaczkę („Procesy o czary w Prusach Książęcych (Brandenburskich) w XVI-XVIII wieku”, Toruń 2007).

Podobnie jak recenzowana przez niego praca M. Pilaszek, także jego własna książka spotkała się z mieszanym przyjęciem w polskim środowisku naukowym. $\mathrm{Z}$ jednej strony, w recenzjach podkreślano, jak nieocenionym punktem wyjścia dla przyszłych badaczy może stać się publikacja oraz zawarte w niej przykłady i wypiski źródłowe ${ }^{40}$, z drugiej jednak, nie stroniono od komentarzy negatywnych. Andrzej Karpiński podkreślał braki w podstawowej angielskiej, amerykańskiej i francuskiej literaturze przedmiotu ${ }^{41}$, niedostatki w analizie przytaczanych źródeł ${ }^{42}$, brak badań kwantytatywnych (które mogłyby wesprzeć niektóre z wysuwanych przez autora wniosków $)^{43}$, czy wyciąganie wniosków ogólnych z jednostkowych przykładów ${ }^{44}$.

36 M. Pilaszek, Procesy o czary w Polsce w wiekach XV-XVIII, Kraków 2007, rec. J. Wijaczka, Procesy o czary w Polsce w epoce wczesnonowożytnej, „Kwartalnik Historyczny”, z. 3, 2009, s. 114-115.

37 Tamże, s. 116.

38 Tamże, s. 117.

39 Tamże, s. 118-121.

40 J. Wijaczka, Procesy o czary w Prusach Ksiażęcych (Brandenburskich) w XVI-XVIII wieku, Toruń 2007, rec. J. M. Łapo, „Komunikaty Warmińsko-Mazurskie” 1/2008, s. 79; J. Wijaczka, Procesy o czary w Prusach Ksiązęcych (Brandenburskich) w XVI-XVIII wieku, Toruń 2007, rec. A. Karpiński, Pośród pruskich wiedźm, „Przegląd Historyczny”, tom. XCIX, z. 2, s. 293-299.

41 A. Karpiński, Pośród..., s. 294.

42 Tamże, m.in.: s. 296-298.

43 Tamże, s. 296.

44 Tamże, s. 298. 
Pomimo zarzutów recenzentów, także i w tym przypadku synteza autorstwa J. Wijaczki stanowi aktualnie na gruncie polskim najpełniejsze i najbardziej aktualne ujęcie podjętego tematu.

W 2009 roku T. Wiślicz opublikował artykuł poświęcony wyobrażeniu diabła w kulturze staropolskiej („Talking to the Devil in the Early Modern Popular Imagination”), w 2012 roku zaś tekst nieco swobodniej związany z opisywaną tematyką: „Bezczeszczenie zwłok a podejrzenie o wampiryzm w Karpatach (XVII-XIX w.)”. W 2014 roku ukazała się również recenzja jego autorstwa książki Pawła Rutkowskiego, „Demon osobisty w Anglii wczesnonowożytnej”, którą to monografię pomijam w niniejszym artykule ze względu na przedmiot którego dotyczy (Anglia wczesnonowożytna, a nie Polska).

Na koniec trzeba wspomnieć o dwóch monografiach, które ukazały się w 2016 roku, a które z odmiennych (i częściowo uzupełniających się) perspektyw przedstawiają stanowisko polskiego Kościoła wobec procesów o czary. Pierwsza praca, autorstwa Bartosza Marcińczaka ${ }^{45}$, poświęcona została analizie dwóch XVIII-wiecznych książek: „Diabła w swojej postaci” Jana Bohomolca oraz „Nowych Aten” Benedykta Chmielowskiego. Szczegółowa lektura tych dwóch tekstów pozwoliła autorowi wysunąć tezę o niesłuszności dotychczasowej oceny obu duchownych, dzięki czemu uniknął wartościującego podziału XVIII-wiecznych teoretyków kwestii czarownictwa na „zacofanych” zwolenników i „postępowych” przeciwników zjawiska ${ }^{46}$. Marcińczakowi udało się pokazać po jak cienkiej linii kroczyli zarówno Jan Bohomolec, jak i Benedykt Chmielowski, którzy z jednej strony starali się przekazać swoje osobiste poglądy na sprawę, a z drugiej manewrowali w ramach swoich prac tak, aby nie zrazić do siebie całkowicie obu, skrajnych stron dyskusji na temat czarownictwa. Zarówno „Diabeł w swojej postaci”, jak i „Nowe Ateny” stanowią, w ujęciu autora monografii, przejaw naukowego podejścia do kwestii demonologicznych, o tyle przy tym ciekawy, że wychodząc z tego samego założenia i wykorzystując podobną aparaturę pojęciową, dochodzą ostatecznie do zupełnie przeciwstawnych wniosków ${ }^{47}$.

Druga ze wspomnianych monografii to jeszcze jedna praca J. Wijaczki, tym razem skupiona na analizie zjawiska w zachodnich i centralnych prowincjach państwa polsko-litewskiego poprzez pryzmat dokumentów kościelnych ${ }^{48}$. Autor wychodzi od

45 B. Marcińczak, Między tacnowiernością a niewiernością. Diabeł, magia i czary w „Nowych Atenach” $i$ „Diable w swojej postaci", Warszawa 2014.

46 B. Marcińczak, Między tacnowiernością a niewiernością. Diabet, magia i czary w „Nowych Atenach” $i$ „Diable w swojej postaci”, Warszawa 2014, rec. W. Pawlik-Kwaśniewska, Idea i ideologizacja czarownictwa w interpretacji Bartosza Marcińczaka, „Klio”, t. XXXII (2015), s. 218.

47 Tamże.

48 J. Wijaczka, Kościót wobec czarów w Rzeczypospolitej w XVI-XVIII wieku (na tle europejskim), Warszawa 2016. 
nakreślenia stosunku Kościoła (w skali europejskiej) do zjawiska czarów w późnym średniowieczu, powstania pierwszych dostępnych w szerokim obiegu prac demonologicznych oraz przedstawienia polskiej specyfiki XV-wiecznych procesów o czary (rozdział I: „Kościół a czary w późnym średniowieczu”, s. 23-62). Dalej przechodzi do opisu ewolucji problemu na przełomie średniowiecza i czasów nowożytnych (skupiając się przede wszystkim na jego charakterystyce w Hiszpanii, księstwach Rzeszy oraz stosunku doń papiestwa; rozdział II: „Od średniowiecza do Instrukcji rzymskiej (1657)”, s. 63-114). Druga połowa książki poświęcona została w całości kwestiom polskim. W trzecim rozdziale pracy J. Wijaczka przedstawia indywidualny stosunek poszczególnych biskupów do problemu czarownic („Biskupi w państwie polsko-litewskim a czary", s. 115-168). W tej części pracy uwzględnione zostały napomnienia i dekrety biskupie z diecezji włocławskiej, płockiej, krakowskiej, łuckiej, poznańskiej, chełmińskiej, kijowskiej, wileńskiej i żmudzkiej. W rozdziale ostatnim książki („Niższe duchowieństwo wobec czarostwa”, s. 169-216) J. Wijaczka podjął temat edukacji kleru parafialnego, jego wyobrażeń demonicznych oraz stosunku do zjawiska czarów. W przyszłości praca stanowić będzie zapewne ważny punkt odniesienia dla innych badaczy, nie tylko tych podejmujących temat stosunku Kościoła polskiego do czarownic, ale także - ze względu na syntetyczne ujęcie problemu mentalności wiejskich duchownych - również dla tych prowadzących badania podstawowe na gruncie mikrohistorii.

Pomimo tego, że od wspomnianego na wstępie apelu K. Sochaniewicza minęło już blisko sto lat, dzisiejszy stan polskich badań nad procesami o czary nadal pozostawia wiele do życzenia. Wymienione powyżej syntezy problemu autorstwa B. Baranowskiego, M. Pilaszek oraz J. Wijaczki, chociaż potrzebne, nie zastąpią jednak zakrojonych na szeroką skalę badań podstawowych. Obecnie mamy bowiem do czynienia z sytuacją, w której artykuly i książki poświęcone pomniejszym problemom czarownictwa w okresie nowożytnym nadal są w powijakach, a zamiast nich, kolejni autorzy przygotowują duże ujęcia syntetyczne, oparte jednak głównie na własnych, siłą rzeczy ograniczonych, badaniach podstawowych. Jedynym wyjściem z sytuacji wydaje się tworzenie mniejszych lub większych zespołów badawczych, które w szczególności skupiłyby się na przeprowadzaniu dokładnej kwerendy źródłowej i publikowaniu dokonywanych przez siebie odkryć, $\mathrm{w}$ celu udostępnienia szerokiemu gronu odbiorców informacji na temat istnienia konkretnych przekazów źródłowych. Rozproszenie zapisków sądów nowożytnych stanowi bowiem główną przeszkodę w prowadzeniu kompleksowych badań nad problemem polskich procesów o czary. 
Obecnie podobnego zadania podjął się m.in. Michael Ostling ${ }^{49}$, pod którego kierunkiem powstaje internetowa baza danych zbierająca informacje na temat polskich procesów o czary (The Polish Witch-Trial Database) - wstępna data publikacji byla przewidziana na kwiecień 2015 roku, prace nad nią nadal jednak przeciągają się i trudno określić, kiedy zostanie upubliczniona. Niezależnie od działań amerykańskiego historyka, konieczne wydaje się jednak powstawanie kolejnych tego typu grup, ponieważ bez ich udziału przyrost nowej wiedzy pozostanie minimalny, a nasza świadomość na temat skali zjawiska ograniczona do domysłów, opartych na wąskim wycinku nowożytnych przekazów źródłowych.

49 Michael Ostling - amerykański historyk związany z uniwersytetami w Toronto i Queensland. Autor szeregu prac poświęconych zagadnieniu procesów o czary, również na gruncie polskim. M. Ostling, Nieznany proces o czary i świętokradztwo w Lublinie, 1643, „Lud”, t. LXXXIX, s. 191-203; Tenże, Konstytucja 1543 r. i początki procesów o czary w Polsce, „Odrodzenie i Reformacja w Polsce”, t. XLIX (2009), s. 93-103; Tenże, Between the Devil and the Host. Imaging Witchcraft in Early Modern Poland, Oxford 2011; Tenże, Poison and Enchantment Rule Ruthenia. Witchcraft, Superstition, and Ethnicity in the Polish-Lithuanian Commonwealth, „Russian History”, t. XL (2013), s. 488-507. 